\title{
Analisis Pengaruh Profitabilitas dan Kebijakan Dividen Terhadap Nilai Perusahaan dengan Struktur Modal sebagai Variabel Mediasi
}

\author{
Ready Wicaksono \\ Sekolah Tinggi Ilmu Ekonomi \\ Balikpapan, Balikpapan, Indonesia \\ ready@stiebalikpapan.ac.id
}

Corresponding Author : Mispiyanti

Submitted: 2 Juni 2020

Accepted: 1 Agustus 2020

Published: 1 Agustus 2020

\author{
Mispiyanti \\ Sekolah Tinggi Ilmu Ekonomi \\ Putra Bangsa, Kebumen, Indonesia \\ mispiyanti@gmail.com
}

\begin{abstract}
This study aims to determine the relationship and influence of profitability variables, and dividend policy on firm value and capital structure variables as a mediator. The population is all state-owned companies listed on the Stock Exchange during 2015 - 2018. The sampling technique uses purposive sampling. Data analysis used regression and multiple tests. The results of this study prove that profitability has no effect on firm value but does affect the capital structure, dividend policy has an effect on firm value and also on capital structure, capital structure has no effect on firm value, the capital structure cannot mediate the relationship of profitability and dividend policy on firm value.
\end{abstract}

Keywords: firm value, capital structure, profitability, dividend policy

\begin{abstract}
ABSTRAK
Penelitian ini bertujuan untuk mengetahui hubungan dan pengaruh variabel profitabilitas, dan kebijakan dividen terhadap nilai perusahaan serta variabel struktur modal sebagai pemediasi. Populasinya adalah semua perusahaan BUMN yang terdaftar di BEI selama tahun 2015 - 2018. Teknik pengambilan sampel menggunakan purposive sampling. Analisis data digunakan path analysis dan sobel test. Hasil penelitian ini membuktikan bahwa profitabilitas tidak berpengaruh terhadap nilai perusahaan tetapi berpengaruh terhadap struktur modal, kebijakan dividen berpengaruh terhadap nilai perusahaan dan struktur modal, struktur modal tidak berpengaruh terhadap nilai perusahaan, struktur modal tidak dapat memediasi hubungan profitabilitas dan kebijakan dividen terhadap nilai perusahaan.
\end{abstract}

Keywords : nilai perusahaan, struktur modal, profitabilitas, kebijakan dividen

\section{PENDAHULUAN \\ Latar Belakang}

Perkembangan BUMN sangat pesat pada tahun 2004, namun mengalami penurunan karena adanya merger, dan holding beberapa BUMN. Pada tahun 2017, BUMN yang memperoleh peningkatan laba ada 38 perseroan dan 3 
perseroan memperoleh pertumbuhan negatif. Namun tahun 2018, hanya 34 perseroan BUMN yang memperoleh laba dan 7 (tujuh) perseroan BUMN yang mengalami kinerja keuangannya menurun. Berbagai upaya penyehatan dilakukan pemerintah melalui opsi restrukturisasi. Di antaranya, melibatkan Penyertaan Modal Negara (PMN), opsi menarik investor strategis hingga melakukan holdingisasi BUMN.

Perusahaan yang nilainya tinggi menunjukkan kinerja perusahaan yang baik. Tingginya nilai perusahaan berdampak pada kesejahteraan para pemegang saham. Salah satu faktor yang dapat mempengaruhi nilai perusahaan yaitu profitabilitas. Sebagaimana hasil penelitian Indasari and Yadnyana (2018) dan Hauteas and Muslichah (2019) yang menunjukkan semakin tinggi tingkat profitabilitas maka semakin tinggi nilai perusahaan sehingga semakin besar kemakmuran yang akan dibagikan kepada pemegang saham, oleh karena itu tingkat profitabilitas berpengaruh positif pada nilai perusahaan. Gunawan (2016) juga menemukan bahwa Net Profit Margin berpengaruh positif terhadap rasio Tobin's Q. Sedangkan (Mispiyanti, 2020) menemukan bahwa profitabilitas berpengaruh negatif terhadap nilai perusahaan. Selain itu, profitabilitas juga bisa berpengaruh terhadap struktur modal. Hal tersebut ditunjukkan oleh hasil penelitian (Hauteas and Muslichah, 2019) yaitu perusahaan yang profitable cenderung menggunakan dana utang untuk operasi perusahaan seperti ekspansi guna mendorong peningkatan laba di masa yang akan datang. Anjarwati et al., (2015) menemukan bahwa Profitabilitas (NPM) menunjukkan berpengaruh negatif dan signifikan terhadap Struktur Modal (DER).

Selain dipengaruhi profitabilitas, nilai perusahaan juga dapat dipengaruhi oleh kebijakan dividen. Kebijakan dividen dari BUMN merupakan isu yang paling penting bagi bagi perkembangan dari BUMN tersebut dan penerimaan negara. Apakah laba BUMN lebih digunakan untuk membiayai investasi atau diberikan sebagai dividen yang kemudian digunakan untuk membiayai belanja pemerintah. Jika perusahaan memutuskan tidak ada peningkatan pembagian dividen maka berdampak pada harga saham yaitu bisa menurun dan nilai perusahaan bisa juga menurun dan begitu juga sebaliknya. Oleh karena itu kebijakan dividen dapat mempengaruhi nilai perusahaan jika dilihat dari bagaimana perusahaan membuat keputusan dalam kebijakan dividen. Senata, (2016), (Rasyid and Yuliandhari, 2018) dan (Mispiyanti, 2020) menyatakan bahwa kebijakan dividen berpengaruh terhadap nilai perusahaan. Struktur modal dapat juga dipengaruhi oleh kebijakan dividen. Hauteas and Muslichah (2019) kebijakan dividen berpengaruh signifikan terhadap struktur modal. Namun (Musabbihan and Purnawati, 2018) menemukan kebijakan dividen berpengaruh positif tidak signifikan terhadap struktur modal.

Salah satu aspek penting yang bisa mempengaruhi nilai perusahaan adalah struktur modal. Hal ini berdasarkan hasil penelitian (Hauteas and Muslichah, 2019) struktur modal berpengaruh signifikan terhadap nilai perusahaan. Hal ini sesuai dengan trade off theory yang menyatakan bahwa jika posisi struktur modal berada di bawah titik optimal maka setiap peningkatan utang akan meningkatkan nilai dari perusahaan tersebut dan sebaliknya jika posisi struktur modal tersebut berada di atas titik optimal maka setiap peningkatan utang akan menurunkan nilai perusahaan.

Dari penjelasan-penjelasan diatas, diketahui profitabilitas, dan kebijakan dividen dapat berpengaruh terhadap nilai perusahaan, selanjutnya pengaruh profitabilitas, dan kebijakan dividen terhadap struktur modal masih menghasilkan temuan yang belum 
konsisten. Penelitian ini mengkaji analisis pengaruh profitabilitas dan kebijakan dividen terhadap nilai perusahaan dengan struktur modal sebagai variabel mediasi pada perusahaan BUMN. Berdasarkan penjelasan diatas, maka tujuan penelitian ini yaitu menganalisis hubungan dan pengaruh variabel profitabilitas, dan kebijakan dividen terhadap nilai perusahaan serta variabel struktur modal sebagai pemediasi.

\section{KAJIAN TEORI}

\subsection{Signalling Theory}

Signaling theory ditemukan oleh Spence (1973) dalam Furqoni and Asandimitra (2019) menjelaskan bagaimana sinyal yang diberikan pihak pemilik informasi dapat mempengaruhi penerima sinyal tersebut untuk tertarik maupun sebagai masalah bagi pengirim sinyal serta keputusan berinvestasi bagi para pengguna laporan keuangan. Teori sinyal ini juga mengemukakan tentang cara perusahaan memberikan sinyal seperti informasi mengenai apa yang sudah dilakukan oleh manajemen untuk merealisasikan keinginan investor. Oleh karena itu, teori sinyal (signaling theory) merupakan upaya untuk memaksimalkan nilai perusahaan.

\subsection{Nilai perusahaan}

Nilai perusahaan adalah nilai wajar dari suatu perusahaan yang menggambarkan persepsi investor terhadap emiten yang bersangkutan.Nilai perusahaan juga dapat diartikan sebagai nilai pasar.Nilai pasar perusahaan yang dibentuk melalui indikator nilai pasar saham merupakan cerminan dari nilai aset perusahaan sesungguhnya. Nilai pasar saham ini sangat dipengaruhi oleh banyak peluang investasi. Adanya banyak peluang investasi tersebut merupakan sinyal positif tentang pertumbuhan perusahaan dimasa yang akan datang, sehingga meningkatkan nilai perusahaan (Kurnia, 2017). Pada penelitian ini, nilai perusahaan diproksikan dengan Tobin's Q. Tobin's Q merupakan rasio yang memberikan informasi paling baik karena dalam Tobin's Q memasukkan semua unsur yaitu hutang, modal, serta seluruh aset perusahaan. Nilai Tobin's Q menggambarkan suatu kondisi peluang investasi yang dimiliki perusahaan (Kurnia, 2017). Jika nilai Tobin's Q menunjukkan diatas satu akan dapat menimbulkan atau meningkatkan minat para investor baru yang menunjukkan bahwa investasi dalam aktiva menghasilkan laba yang lebih tinggi. Bila nilai Tobin's Q dibawah satu maka investasi kepada perusahaan tersebut kurang menarik.

\subsection{Profitabilitas}

Bagi perusahaan, laba yang besar belumlah merupakan ukuran bahwa perusahaan itu telah bekerja dengan efisien. Efisiensi baru dapat diketahui dengan membandingkan laba tersebut, atau dengan kata lain menghitung tingkat profitabilitasnya. Semakin tinggi profitabilitas perusahaan maka mencerminkan bahwa semakin tinggi tingkat efisiensi perusahaan. Selain itu, semakin besar profitabilitas yang dimiliki oleh perusahaan, maka perusahaan akan memilih menggunakan keuntungan tersebut untuk membiayai kegiatan operasinya yang dapat mengurangi penggunaan utang.

\subsection{Bird in The Hand Theory}

Menurut Baker et al dalam Antoro and Hermuningsih (2017), bird in the hand theory menyatakan bahwa investor lebih menyukai dividen tunai dari pada dijanjikan adanya imbal hasil atas investasi (capital gain) di masa yang akan datang, karena menerima dividen tunai merupakan bentuk dari kepastian yang berarti mengurangi risiko. Menurut Esana and Darmawan (2017), pembagian dividen merupakan suatu pertanda bagi investor, dimana kenaikan dividen yang 
sangat besar menandakan bahwa manajemen merasa optimis atas masa depan perusahaan. Hal tersebut merupakan sinyak positif bagi calon investor/investor untuk memutuskan berinvestasi pada perusahaan tersebut, sehingga nantinya akan mempengaruhi nilai perusahaan.

\subsection{Kebijakan dividen}

Menurut Zurohtun and Yulianti (2013) kebijakan dividen adalah suatu keputusan untuk menentukan berapa besar bagian dari pendapatanperusahaan akan dibagikan kepada para pemegang saham dan akan diinvestasikan kembali atau ditahan di dalam perusahaan. Besarnya dividen di Indonesia yang akan dibagikan ditentukan dalam rapat umum pemegang saham (RUPS). Kebijakan dividen perusahaan tercermin dalam rasio pembayaran dividen (dividend payout ratio). Dividend Payout Ratio adalah perbandingan antara dividen yang dibayarkan dengan laba bersih yang didapatkan dan biasanya disajikan dalam bentuk prosentase. Dividen merupakan pembagian keuntungan perusahaan kepada para pemegang saham yang sebanding dengan jumlah lembar saham yang dimilikinya. Dalam pembayaran dividen, perusahaan dapat menggunakan bentuk-bentuk tertentu, seperti dividen tunai, dividen dalam bentuk aktiva yang lain, dividen dalam bentuk surat utang ataupun dividen dalam bentuk saham (Zurohtun and Yulianti, 2013).

\subsection{Pecking Order Theory}

Pecking order theory (Myers, 1984) dalam Lestari (2015) mengasumsikan bahwa perusahaan bertujuan untuk memaksimumkan kesejahteraan pemegang saham. Pecking order theory merupakan teori yang menjelaskan adanya hirarki pendanaan yang dilakukan perusahaan yaitu pertama kali menggunakan pendanaan internal, kemudian jika diperlukan akan menggunakan pendanaan eksternal. Teori pecking order ini menganut keputusan pendanaan dengan urutan preferensi logis investor terhadap prospek perusahaan dan konsisten pada tujuan, agar manajer mampu memaksimumkan kemakmuran pemegang saham. Apabila dana internal lebih besar maka perusahaan akan menggunakannya untuk melunasi hutang atau berinvestasi pada surat berharga. Sebaliknya apabila perusahaan mengalami defisit, maka perusahaan akan menurunkan saldo kas atau menjual surat berharga tersebut. Asumsi

lainnya lainnya bahwa ketika perusahaan memerlukan sumber dana tambahan, mereka cenderung memilih hutang lebih dulu kemudian sekuritas (Myers dan Majluf dalam Harjito, 2011)

\subsection{Teori trade-off}

Myers (1984) dalam (Culata and Gunarsih, 2012) menyatakan bahwa $a$ firm that follows the tradeoff theory sets a target debt-to-value ratio and then gradually moves towards the target. Menurut teori ini struktur modal yang optimal dicapai, apabila nilai sekarang dari tax shield hutang adalah sama dengan nilai sekarang dari biaya kesulitan keuangan hutang. Teori trade-off menyatakan bahwa terdapat rasio hutang yang optimal atau struktur modal yang optimal di dalam keuangan perusahaan. Namun sebaliknya, perusahaan membuat keputusan struktur modal berdasarkan sumber modal yang paling mahal biaya modalnya. Itu adalah sumber modal yang kurang sensitif terhadap masalah asimetri informasi yang mengikuti urutan srukturnya, yaitu mulai dari laba ditahan; diikuti oleh hutang dan terakhir ekuitas. Pada dasarnya, tambahan hutang masih dapat dilakukan (ditoleransi) oleh perusahaan selama manfaat yang diberikan masih lebih besar daripada biaya akibat hutang itu sendiri, selain itu tambahan hutang masih dilakukan selama masih adanya aset tetap sebagai jaminan, 
tetapi jika biaya hutang sudah terlalu tinggi, perusahaan seharusnya tidak menambah hutang lagi untuk menghindari resiko yang tidak diinginkan. Di sisi lain, teori ini juga menyatakan bahwa suatu perusahaan tidak akan mencapai nilai optimal jika pendanaan dibiayai oleh hutang sepenuhnya atau tidak menggunakan hutang sama sekali (Farisa and Widati, 2017).

\subsection{Struktur Modal}

Struktur modal adalah proporsi pendanaan dengan hutang perusahaan.Perusahaan dengan tingkat pengembang usaha yang besar akan membutuhkan sumber dana yang besar, sehingga dibutuhkan tambahan dana dari pihak eksternal sebagai upaya untuk menambah kebutuhan dana dalam proses pengembangan usaha. Perusahaan dengan tingkat pengembangan usaha yang baik dalam jangka panjang akan memberikan keuntungan yang besar kepada investor (Dhani and Utama, 2017). Pada dasarnya semua struktur modal adalah baik. Namun jika dengan merubah struktur modal didapatkan nilai perusahaan berubah, maka dapat diperoleh struktur modal terbaik. Struktur modal yang paling baik ialah yang mampu meningkatkan nilai perusahaan dan harga saham Husnan dalam (Kusumastuti et al., 2017).

\subsection{Hipotesis Penelitian}

\section{Pengaruh Profitabilitas Terhadap Nilai} Perusahaan

Profitabilitas dari perusahaan biasanya dijadikan salah satu faktor penilaian pasar terhadap perusahaan tersebut. Berdasarkan signaling theory, profitabilitas merupakan salah satu cara perusahaan dalam memberikan informasi terkait profit yang telah dilakukan manajemen guna merealisasikan keinginan para investor. Dalam penelitian ini, profitabilitas diwakilkan dengan $\mathrm{Net}$ Profit Margin (NPM). Rasio net profit margin yaitu rasio pendapatan terhadap penjualan. Semakin tinggi rasio tersebut maka kemampuan memperoleh laba oleh perusahaan akan semakin besar. Musabbihan and Purnawati (2018) menemukan bahwa profitabilitas berpengaruh positif terhadap nilai perusahaan. Profitabilitas yang besar pada suatu perusahaan dapat digunakan oleh investor dalam pengambilan keputusan untuk berinvestasi dengan melakukan pembelian saham emiten.Hal tersebut dilakukan karena laba bersih yang meningkat mampu mempengaruhi minat investor untuk menginvestasikan dananya di perusahaan, yang nantinya akan berdampakpada peningkatan nilai perusahaan. Hal ini didukung oleh Gunawan (2016) yang menemukan bahwa net profit margin berpengaruh positif terhadap rasio Tobin's Q. Berdasar uraian di atas, dapat disimpulkan hipotesis pertama penelitian ini adalah sebagai berikut :

$\mathrm{H}_{1}$ :Profitabilitas berpengaruh terhadap nilai perusahaan

\section{Pengaruh Kebijakan Dividen Terhadap Nilai Perusahaan}

BUMN memiliki kebijakan pembayaran dividen yang berbeda. Hal ini disebabkan BUMN dituntut untuk memberikan dividen sebanyakbanyaknya, karena dividen BUMN akan masuk dalam APBN. BUMN yang sudah go publik lebih diperhatikan kinerjanya, karena diharapkan dengan program privatisasi kinerja BUMN akan meningkat. Widyanti (2014) menyatakan kebijakan dividen berpengaruh terhadap nilai perusahaan. (Antoro and Hermuningsih, 2017) dan Mispiyanti (2020) menyatakan bahwa kebijakan dividen berpengaruh positif dan signifikan terhadap nilai perusahaan, karena investor lebih menyukai dividen tunai daripada dijanjikan adanya imbal hasil atas investasi (capital gain) di masa yang akan datang. Hal ini didukung juga oleh theory bird in the hand, dimana pembagian dividenmerupakan suatu pertanda bagi 
investor. Berdasar uraian di atas, dapat disimpulkan hipotesis kedua penelitian ini adalah sebagai berikut :

$\mathrm{H}_{2}$ :Kebijakan dividen berpengaruh terhadap nilai perusahaan

\section{Pengaruh Profitabilitas Terhadap Struktur Modal}

Perusahaan yang memiliki tingkat profitabilitas tinggi, manajemen perusahaan dapat memperkuat struktur permodalan, karena perusahaan dengan profitabilitas tinggi akan memilih untuk membiayai dirinya sendiri terlebih dahulu. Apabila perusahaan menggunakan laba ditahan sebagai penambah modalnya maka dapat mengurangi hutang yang dimiliki perusahaan tersebut. Hal ini sesuai dengan pecking order theory, dimana perusahaan lebih menyukai pembiayaan dengan sekuritas paling aman yaitu laba ditahan, kemudian baru penggunaan dana ekstenal dengan hutang dan penjualan saham. Hasil penelitian Wijaya and Utama (2014) menyatakan bahwa profitabilitas memiliki pengaruh signifikan pada struktur modal. (Dewi and Sudiartha, 2017) menemukan profitabilitas berpengaruh positif dan signifikan terhadap struktur modal, karena perusahaan yang melakukan ekspansi membutuhkan banyak dana untuk mendorong penambahan laba di masa yang akan datang. (Hauteas and Muslichah, 2019) menemukan bahwa profitabilitas berpengaruh positif signifikan terhadap struktur modal.

Berdasarkan hal di atas, maka dapat disimpulkan bahwa

$\mathrm{H}_{3}$ :Profitabilitas berpengaruh terhadap struktur modal

\section{Pengaruh Kebijakan Dividen Terhadap Struktur Modal}

Kebijakan dividen merupakan keputusan perusahaan dalam menentukan jumlah dividen dan kapan dividen dibagikan kepada pemegang saham. Berdasarkan bird in the hand theory, investor lebih menyukai dividen tunai dari pada capital gain. Jika jumlah dividen yang dibagikan terlalu banyak maka akan mengurangi laba ditahan sehingga kesempatan untuk menggunakan sumber dana internal perusahaan akan berkurang. Sehingga perusahaan perlu mencari tambahan dana eksternal seperti dengan penerbitan saham baru atau obligasi. Apabila dilakukan keduanya maka akan berpengaruh terhadap struktur modal jika menerbitkan saham baru ekuitas perusahaan akan naik dan jika menerbitkan obligasi, utang perusahaan akan bertambah. (Eviani, 2015) menemukan bahwa dividend payout ratio memiliki pengaruh signifikan terhadap struktur modal. Ulfah (2016) menemukan bahwa kebijakan dividen dapat mengubah capital structure (DER), karena laba perusahaan lebih banyak dibagikan untuk dividen maka kebutuhan dana untuk investasi akan dipenuhi melalui utang. Berdasarkan hal di atas, maka dapat disimpulkan bahwa

$\mathrm{H}_{4} \quad$ :Kebijakan dividen berpengaruh terhadap struktur modal

Pengaruh Struktur Modal Terhadap Nilai Perusahaan

Struktur modal merupakan proporsi pembiayaan jangka panjang permanen perusahaan yang terdiri dari saham preferen, ekuitas saham biasa dan hutang. Jika perusahaan menggunakan utang jangka panjang untuk membiayai asetnya maka nilai perusahaan dapat ditingkatkan. Pernyataan tersebut sesuai dengan teori trade off dimana perusahaan dapat memanfaatkan utang selagi ada manfaatnya (penghematan biaya pajak dan biaya lainnya dibandingkan dengan membayar bunga. Selain itu dalam signaling theory menjelaskan bahwa apabila dana internal perusahaan digunakan untuk membiayai usahanya sehingga investor akan melihat sebagai sinyal positif. Supit et al., (2015) menemukan bahwa struktur modal berpengaruh signifikan terhadap nilai perusahaan. Kemudian (Hauteas and Muslichah, 2019) menemukan bahwa 
struktur modal memiliki pengaruh positif dan signifikan terhadap nilai perusahaan karena jika posisi struktur modal berada di bawah titik optimal maka setiap peningkatan utang akan meningkatkan nilai dari perusahaan dan sebaliknya jika posisi struktur modal berada di atas titik optimal maka setiap peningkatan utang akan menurunkan nilai perusahaan. Berdasarkan hal di atas, maka dapat disimpulkan bahwa

$\mathrm{H}_{5}$ :Struktur Modal berpengaruh terhadap Nilai Perusahaan

\section{Pengaruh Profitabilitas Terhadap Nilai} Perusahaan Melalui Struktur Modal

Apabila profitabilitas perusahaan baik maka para kreditur, supplier, dan juga investor akan melihat sejauh mana perusahaan dapat menghasilkan laba dari penjualan dan investasi perusahaan. Semakin tinggi tingkat profitabilitas juga akan semakin tinggi pula utang perusahaan. Dalam perspektif pemegang saham, penggunaan dana berasal dariutang lebih menguntungkan jika dibandingkan dengan pendanaan ekuitas. Hal ini sesuai dengan trade off theory yang menyatakan bahwa suatu perusahaan tidak akan mencapai nilai optimal jika pendanaan dibiayai sepenuhnya oleh utang atau tidak menggunakan utang sama sekali. Ketika perusahaan menggunakan utang untuk mendanai suatu proyek tertentu, berarti perusahaan sudah yakin bahwa proyek tersebut memberikan tingkat pengembalian baik dan cukup untuk membayar utang perusahaan. Kebijakan tentang struktur modal tersebut merupakan sinyal positif terhadap investor sehingga akan meningkatkan nilai perusahaan. Purnomo and Erawati, (2019) menemukan bahwa perusahaan yang memiliki kinerja yang baik berarti perusahaan dapat mengoptimalkan struktur modal dalam pendanaan perusahaan yang nantinya akan mempengaruhi nilai perusahaan. (Musabbihan and Purnawati, 2018) dan Hauteas and Muslichah,2019) menemukan bahwa struktur modal memediasi pengaruh profitabilitas dan kebijakan dividen terhadap nilai perusahaan. Dari uraian diatas dapat dirumuskan hipotesis penelitian sebagai berikut:

$\mathrm{H}_{6}$ :Profitabilitas berpengaruh terhadap nilai perusahaan melalui struktur modal

\section{Pengaruh Kebijakan Dividen Terhadap Nilai Perusahaan Melalui Struktur Modal}

Perusahaan dapat melakukan pengurangan laba ditahan akibat pembagian deviden, sehingga perusahaan untuk membiayai kebutuhan dananya memerlukan dana eksternal yaitu penerbitan utang dan saham. Secara keseluruan pembayaran dividen akan dilakukan sepenuhnya apabila perusahaan mendapatkan laba atau keuntungan. Apabila perusahaan membagikan dividennya rendah kepada pemegang saham akan memberikan sinyal kepada pasar bahwa perusahaan memiliki keuntungan yang rendah, sehingga perusahaan akan mencari dana eksternal kepada pihak luar berupa utang untuk memenuhi kebutuhannya. Khoirianto (2016) menemukan bahwa struktur modal dapat memediasi pengaruh kebijakan dividen terhadap nilai perusahaan. Hauteas and Muslichah (2019) juga menemukan struktur modal memediasi pengaruh kebijakan dividen terhadap nilai perusahaan.

Berdasarkan hal tersebut maka hipotesis kelima penelitian ini adalah:

$\mathrm{H}_{7}$ :Kebijakan dividen berpengaruh terhadap nilai perusahaan melalui struktur modal

\section{Kerangka Pemikiran}

Berikut adalah kerangka pikir dalam penelitian ini.

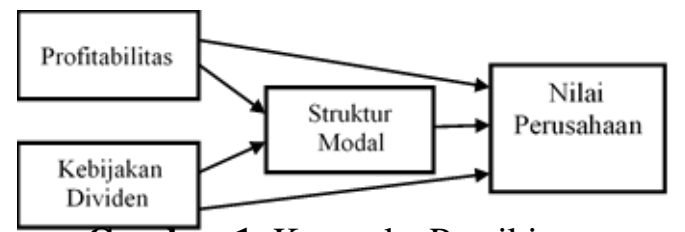

Gambar 1. Kerangka Pemikiran 


\section{METODE PENELITIAN}

\subsection{Populasi dan Sampel}

Kinerja BUMN di Indonesia selalu menjadi perhatian karena menjadi salah satu penyumbang penerimaan negara. Ketika kinerja BUMN selalu mengalami kenaikan maka akan berdampak pada penilaian terhadap perusahaanperusahaan BUMN tersebut. Populasi dalam penelitian ini adalah semua perusahaan BUMN yang terdaftar di Bursa Efek Indonesia (BEI) selama tahun 2015 - 2018. Berdasarkan populasi tersebut, sampel penelitian ini berdasarkan purposive sampling. Hasil dari pengambilan sampel sebagai berikut:

\begin{tabular}{|l|l|c|}
\hline No. & \multicolumn{1}{|c|}{ Kriteria } & $\begin{array}{c}\text { Jumla } \\
\mathrm{h}\end{array}$ \\
\hline 1 & $\begin{array}{l}\text { Perusahaan BUMN } \\
\text { yang terdaftar di BEI } \\
\text { pada tahun 2015 - 2018 }\end{array}$ & 20 \\
\hline 2 & $\begin{array}{l}\text { Perusahaan BUMN } \\
\text { yang mengalami } \\
\text { kerugian selama } \\
\text { periode penelitian }\end{array}$ & $(4)$ \\
\hline \multicolumn{2}{|l|}{ Sampel } & 16 \\
\hline \multicolumn{2}{|l|}{ Total Pengamatan (16 x 4) } & 64 \\
\hline
\end{tabular}

\subsection{Jenis Data}

Penelitian ini termasuk jenis kuantitatif menggunakan data sekunder tentangprofitabilitas, kebijakan dividen, struktur modal, dan nilai perusahaan pada perusahaan BUMN Indonesia.

\subsection{Metode Pengumpulan Data}

Metode pengumpulan data yang akan digunakan pada penelitian ini adalah metode dokumentasi data sekunder yaitu laporan keuangan perusahaan BUMN yang terdaftar di Bursa Efek Indonesia (BEI).

\subsection{Definisi Operasional Variabel}

Berdasarkan judul penelitian di atas, maka variabel-variabel yang terkait dalam penelitian ini adalah:

\section{Variabel Bebas (X)}

Variabel bebas sering juga disebut dengan variabel independen yang akan mempengaruhi variabel terikat. Adapun variabel bebas dalam penelitian ini adalah:

\section{Profitabilitas}

Profitabilitas adalah kemampuan perusahaan dalam menghasilkan laba. Dalam penelitian ini profitabilitas diproksikan Net Profit Margin (NPM). Rasio NPM menurut (Gunawan, 2016) adalah rasio yang mengukur tingkat keuntungan yang dapat dicapai oleh perusahaan dihubungkan dengan penjualannya. Rumus NPM adalah sebagai berikut:

$$
N P M=\frac{E A I T}{\text { Sales }}
$$

\section{Kebijakan Dividen}

Variabel kebijakan dividen diproksikan dengan Dividend Payout Ratio (DPR), yang merupakan perbandingan antara jumlah dividen yang dibayarkan per lembar saham dan jumlah laba yang dibayarkan per lembar saham. Dividend Payout Ratio ini mengacu pada (Supit et al., 2015).

$$
D P R=\frac{D P S}{L P S}
$$

DPS $=$ Dividen Per lembar Saham

LPS = Laba Per lembar Saham

\section{Variabel Tidak Bebas}

Variabel tidak bebas sering juga disebut dengan variabel dependen yang akan mempengaruhi variabel tidak terikat. Adapun variabel dependen dalam penelitian ini yaitu nilai perusahaan. Perhitungan untuk menentukan nilai perusahaan yaitu Tobin's Q. Tobin's Q ditemukan di dalam penggunaannya, menurut (Sudiyatno and Puspitasari, 2010)

Formulasi rumusnya sebagai berikut:

$$
Q=\frac{M V S+D}{T A}
$$

dimana:

MVS : Market Value Share

D : Debt 
TA : Firm's asset's

(MVS) merupakan nilai pasar saham yang diperoleh dari perkalian jumlah saham yang beredar dengan harga saham (Outstanding Shares* Stock Price). Debt merupakan besarnya nilai pasar hutang, dimana nilai ini dapat dihitung dengan menggunakan persamaan sebagai berikut:

$\mathrm{D}=(\mathrm{AVCL}-\mathrm{AVCA})+\mathrm{AVLT}$.

dimana:

AVCL :Accounting value of the firm's Current Liabilities. $=$ Short Term Debt + Taxes Payable.

AVLTD: Accounting value of the firm's Long Term Debt. = Long Term Debt.

AVCA :Accounting value of the firm's

CurrentAssets. $=$ Cash + Account

Receivable + Inventories.

\section{Variabel Mediasi}

\section{Struktur Modal}

Dalam penelitian ini, struktur modal diwakili oleh DER yang merupakan rasio yang digunakan untuk mengukur keberhasilan kinerja manajer dalam menentukan keputusan struktur modal dan dalam mengelola perusahaan. DER dalam penelitian ini mengacu pada Andrian (2012).

$$
\begin{aligned}
& \text { DER } \\
& =\frac{\text { Total liabilitas }}{\text { Total equity }} \times 100 \%
\end{aligned}
$$

\section{Analisis Data}

Analisis Statistik Deskriptif Analisis statistik deskriptif digunakan untuk memberikan gambaran atau deskripsi mengenai variable-variabel yang digunakan dalam penelitian ini. Selanjutnya untuk menganalisis data penelitian ini digunakan path analysis atau analisis jalur. Path analysis merupakan jenis teknik analisis multivariat yang digunakan untuk menguji pengaruh variabel independen, dengan kata lain menguji pengaruh langsung dan tidak langsung (melalui variabel intervening) variabel independen terhadap variabel dependen yang ditentukan oleh peneliti (Chandrarin,
2017). Model persamaannya adalah sebagai berikut:

$\mathrm{Y}=\beta \mathrm{Y}_{1} \mathrm{X}_{1}+\beta \mathrm{Y}_{2} \mathrm{X}_{2}+$

e............................(6)

$\mathrm{Y}=\beta \mathrm{Y}_{2} \mathrm{X}_{1}+\beta \mathrm{Y}_{2} \mathrm{X}_{2}+\beta \mathrm{Y}_{2} \mathrm{Y}_{1}+$

e..............(7)

Keterangan:

$\mathrm{Y}_{1} \quad$ : Struktur Modal

$\mathrm{X}_{1} \quad$ : Profitabilitas

$\mathrm{X}_{2} \quad$ : Kebijakan Dividen

$\mathrm{Y}_{2} \quad$ : Nilai Perusahaan

Akan tetapi, analisis jalur hanya dapat mendeteksi seberapa besar pengaruhnya saja. Sedangkan untuk mengetahui signifikan atau tidaknya menggunakan uji sobel (Sobel Test).

\section{HASIL DAN PEMBAHASAN}

\subsection{Hasil Analisis Deskriptif}

Berikut adalah hasil gambaran profil data penelitian yang menjelaskan data ratarata, minimum, maksimum dan standar deviasi dari variabel-variabel yang diteliti.

\begin{tabular}{|c|c|c|c|c|}
\hline & $\begin{array}{c}\text { Min } \\
\text { imu } \\
\text { m }\end{array}$ & $\begin{array}{c}\text { Max } \\
\text { imu } \\
\text { m }\end{array}$ & $\begin{array}{c}\text { Mea } \\
\mathbf{n}\end{array}$ & $\begin{array}{c}\text { Std. } \\
\text { Deviation }\end{array}$ \\
\hline $\begin{array}{l}\text { Struktur_ } \\
\text { Modal }\end{array}$ & ,33 & 3,38 & $\begin{array}{r}1,536 \\
1\end{array}$ & ,74967 \\
\hline $\begin{array}{l}\text { Profitabil } \\
\text { itas }\end{array}$ & , 10 & 1,51 & ,3697 & 19367 \\
\hline $\begin{array}{l}\text { Kebijaka } \\
\text { n_- }\end{array}$ & ,00 & ,96 & ,5057 & , 16686 \\
\hline $\begin{array}{l}\text { Nilai_Per } \\
\text { usahaan }\end{array}$ & ,47 & 2,75 & $\begin{array}{r}1,065 \\
4\end{array}$ & ,39574 \\
\hline
\end{tabular}

Tabel 1. Statistik Deskriptif Variabel

Sumber: Hasil output SPSS 22, 2019

Tabel 1. menunjukkan nilai minimum, maksimum, rata-rata dan standar deviasi dari variabel profitabilitas, kebijakan dividen, capital expenditure, nilai perusahaan dan struktur modal.

\subsection{Hasil Pengujian Hipotesis}

Berikut ini disajikan pengaruh langsung 
profitabilitas, kebijakan dividen, terhadap struktur modal dan pengaruh langsung profitabilitas, kebijakan dividen dan struktur modal terhadap nilai perusahaan sebagaimana tersaji dalam tabel 2 .

Tabel 2. Pengaruh Langsung Antar Variabel

\begin{tabular}{|l|r|r|l|}
\multicolumn{1}{|c|}{ Tabel 2. Pengaruh Langsung Antar Variabel } \\
\hline \multicolumn{1}{|c|}{ Pengaruh } & $\begin{array}{c}\text { Koefisi } \\
\text { en } \\
\text { Jalur }\end{array}$ & $\begin{array}{c}\text { P } \\
\text { Val } \\
\text { ue }\end{array}$ & $\begin{array}{l}\text { Ketera } \\
\text { ngan }\end{array}$ \\
\hline $\begin{array}{l}\text { Profitabilitas ---> } \\
\text { Struktur Modal }\end{array}$ & 0,253 & $\begin{array}{r}0,0 \\
55\end{array}$ & $\begin{array}{l}\text { Signifik } \\
\text { an }\end{array}$ \\
\hline $\begin{array}{l}\text { Kebijakan Dividen } \\
\text {----> Struktur } \\
\text { Modal }\end{array}$ & $-0,313$ & $\begin{array}{r}0,0 \\
19\end{array}$ & $\begin{array}{l}\text { Signifik } \\
\text { an }\end{array}$ \\
\hline $\begin{array}{l}\text { Profitabilitas ---> } \\
\text { Nilai Perusahaan }\end{array}$ & 0,02 & $\begin{array}{r}0,8 \\
8\end{array}$ & $\begin{array}{l}\text { Sidak } \\
\text { an }\end{array}$ \\
\hline $\begin{array}{l}\text { Kebijakan Dividen } \\
\text {---> Nilai }\end{array}$ & & 0,0 & Signifik \\
Perusahaan & 0,412 & 03 & an \\
\hline Struktur Modal --- & & 0,4 & $\begin{array}{l}\text { Tidak } \\
\text { Signifik } \\
\text { an }\end{array}$ \\
\hline > Nilai Perusahaan & $-0,099$ & 27 & \\
\hline
\end{tabular}

Sumber: Hasil Output SPSS 22, 2019
Untuk mengetahui pengaruh tidak langsung variabel struktur modal terhadap pengaruh profitabilitas terhadap nilai perusahaan dan pengaruh tidak langsung variabel struktur modal terhadap pengaruh kebijakan dividen terhadap nilai perusahaan menggunakan sobel test dengan menggunakan rumus yang dikembangkan Ghozali (2011) dalam (Rohmah and Wahyudin, 2015). Hasil perhitungan nilai t tersebut dibandingkan dengan nilai $\mathrm{t}$ tabel dengan jumlah $\mathrm{n}=62$ dan $\alpha=0,05$, diperoleh nilai $t$ tabel sebesar 1,669. Jika nilai $t$ hitung lebih besar daripada $t$ tabel maka hipotesis-nya diterima. Berikut ini adalah perhitungannya.

$$
\begin{aligned}
S a b & =\sqrt{b^{2}} S a^{2}+a^{2} S b^{2}+S a^{2} S b^{2} \\
& =\sqrt{(-0,037)^{2}(0,500)^{2}+(0,978)^{2}(0,046)^{2}+(0,500)^{2}(0,046)^{2}} \\
& =\sqrt{(0,001369)(0,25)+(0,956484)(0,002116)+(0,25)(0,002116)} \\
& =\sqrt{0,00034225+(0,002116)+(0,000529)} \\
& =\sqrt{0,00298725} \\
& =0,055 \\
& t=\frac{a b}{\text { Sab }} \quad=\frac{-0,036}{0,055}=-0,657 \\
S a b= & \sqrt{b^{2}} S a^{2}+a^{2} S b^{2}+S a^{2} S b^{2} \\
& =\sqrt{(0.037))^{2}(0,581)^{2}+(-1,405)^{2}(0,046)^{2}+(0,581)^{2}(0,046)^{2}} \\
& =\sqrt{(0,001369)(0,337561)+(1,974025)(0,002116)+(0,337561)(0,002116)} \\
& =\sqrt{(0,00037)+(0,003948)+(0,000674)} \\
& =\sqrt{0,004992} \\
& =0,071 \\
t= & \frac{a b}{S a b}=\frac{-0,051}{0,071}=-0,718
\end{aligned}
$$

\section{Pengaruh Profitabilitas Terhadap Nilai Perusahaan}

Berdasarkan tabel 2., profitabilitas tidak berpengaruh terhadap nilai perusahaan dengan nilai koefisien jalur sebesar 0,02 dengan nilai $\mathrm{p}=0,88(>0,05)$. Hasil tersebut mengindikasikan bahwa profitabilitas tidak berpengaruh terhadap

nilai perusahaan. Oleh karena itu, $\mathrm{H}_{1}$ ditolak.

\section{Pengaruh Kebijakan Dividen Terhadap Nilai Perusahaan}

Berdasarkan tabel 2., kebijakan dividen berpengaruh terhadap nilai perusahaan dengan nilai koefisien jalur sebesar 0,412 dengan nilai $\mathrm{p}=0,003(<0,05)$. Hasil tersebut mengindikasikan bahwa 
kebijakan dividen berpengaruh terhadap nilai perusahaan. Oleh karena itu, $\mathrm{H}_{2}$ diterima.

\section{Pengaruh Profitabilitas Terhadap Struktur Modal}

Berdasarkan tabel 2., profitabilitas berpengaruh terhadap struktur modal dengan nilai koefisien jalur sebesar 0,253 dengan nilai $\mathrm{p}=0,055(<0,05)$. Hasil tersebut mengindikasikan bahwa profitabilitas tidak berpengaruh terhadap struktur modal. Oleh karena itu, $\mathrm{H}_{3}$ ditolak.

\section{Pengaruh Kebijakan Dividen Terhadap Struktur Modal}

Berdasarkan tabel 2., kebijakan dividen berpengaruh terhadap struktur modal dengan nilai koefisien jalur sebesar $-0,313$ dengan nilai $\mathrm{p}=0,019(<0,05)$. Hasil tersebut mengindikasikan bahwa kebijakan dividen berpengaruh terhadap struktur modal. Oleh karena itu, $\mathrm{H}_{4}$ diterima.

\section{Pengaruh Struktur Modal Terhadap Nilai Perusahaan}

Berdasarkan tabel 2., struktur modal tidak berpengaruh terhadap nilai perusahaan dengan nilai koefisien jalur sebesar -0,099 dengan nilai $\mathrm{p}=0,427(>0,05)$. Hasil tersebut mengindikasikan bahwa struktur modal tidak berpengaruh terhadap nilai perusahaan. Oleh karena itu, $\mathrm{H}_{5}$ ditolak.

\section{Pengaruh Profitabilitas Terhadap Nilai} Perusahaan Melalui Struktur Modal

Berdasarkan perhitungan yang sudah dilakukan, nilai t hitung lebih kecil dari nilai t tabel, yaitu $-0,657<1,669$. Variabel intervening tidak memiliki kontribusi dalam model. Jadi struktur modal tidak signifikan sebagai variabel intervening dalam pengaruh profitabilitas terhadap nilai perusahaan. Oleh karena itu, $\mathrm{H}_{6}$ ditolak.

\section{Pengaruh Kebijakan Dividen Terhadap Nilai Perusahaan Melalui Struktur Modal}

Berdasarkan perhitungan yang sudah dilakukan, nilai t hitung lebih kecil dari nilai t tabel, yaitu $-0,718<1,669$. Variabel intervening tidak memiliki kontribusi dalam model. Jadi struktur modal tidak signifikan sebagai variabel intervening dalam pengaruh kebijakan dividen terhadap nilai perusahaan. Oleh karena itu, $\mathrm{H}_{7}$ ditolak.

\section{Pembahasan}

Profitabilitas tidak berpengaruh terhadap nilai perusahaan pada perusahaan BUMN Indonesia pada tahun 2015 - 2018.Hal ini menunjukkan berapapun besar laba yang diperoleh perusahaan dari hasil penjualan tidak mampu meningkatkan nilai perusahaan tersebut. Dalam penelitian ini, nilai perusahaan diukur menggunakan Tobins'Q, dimana tidak hanya mengukur hanya dari nilai pasar saham perusahaan saja tetapi juga nilai pasar hutang yang dibagi dengan total asset perusahaan. Umumnya, profitabilitas berpengaruh terhadap nilai perusahaan, namun hasil penelitian ini berbeda dikarenakan tidak adanya pengaruh yang signifikan antara net profit margin (NPM) terhadap nilai perusahaan lebih disebabkan oleh pandangan secara umum para pemegang saham mengenai kemakmuran yang akan diperolehnya dari hasil investasinya. Para pemegang saham lebih memandang kemakmuran diperoleh berdasarkan harga pasar saham, bukan dari laba akuntansi yang dilaporkan oleh perusahaan (Rosada and Idayati, 2017). Menurut Husnan and Pudjiastuti (2012) memaksimumkan nilai perusahaan tidak identik dengan memaksimumkan laba, apabila laba diartikan sebagai laba akuntansi (yaitu laba yang bisa dilihat pada laporan laba rugi). Sebaliknya, memaksimumkan nilai perusahaan akan identik dengan memaksimumkan laba dalam pengertian ekonomi (economic profit), yaitu jumlah kekayaan yang bisa dikonsumsikan tanpa membuat pemilik kekayaan tersebut menjadi lebih miskin. Hasil penelitian ini tidak sejalan dengan Gunawan (2016) dan Musabbihan and Purnawati (2018) dan 
sejalan dengan Ardimas and Wardoyo (2014) dan Rosada and Idayati (2017) Kebijakan dividen dalam penelitian ini berpengaruh terhadap nilai perusahaan BUMN Indonesia pada tahun 2015 - 2018 dengan arah positif karena nilai koefisien dividen payout ratio sebesar 0,466. Artinya jika rasio DPR mengalami kenaikan maka nilai perusahaan dari perusahaan BUMN tersebut juga akan mengalami kenaikan. Namun jika rasio DPR mengalami penurunan, hal ini juga akan berdampak pada penurunan nilai perusahaan. Hasil penelitian ini sesuai dengan signalling theory yang menyatakan bahwa semakin tinggi rasio pembayaran dividen akan menjadi alat sinyal bagi investor sehingga perusahaan akan mendapatkan kepercayaan yang tinggi dari para investor dan hal ini dapat menaikkan nilai perusahaan. Besarnya dividen perusahaan yang diterima oleh pemegang saham dapat mempengaruhi harga saham perusahaan dan akan berdampak pada nilai perusahaan. Apabila semakin besar dividen yang diterima oleh pemegang saham, maka pandangan para investor terhadap nilai perusahaan akan semakin baik sehingga akan semakin tinggi pula nilai pada suatu perusahaan (Erawati and Sihaloho, 2019). Hasil penelitian ini juga sesuai dengan Bird In The Hand Theory yang menyatakan bahwa investor lebih menyukai dividen tunai daripada capital gain di masa yang akan datang. Hasil penelitian ini sejalan dengan Widyanti (2014) dan Antoro and Hermuningsih (2017).

Profitabilitas pada penelitian ini tidak berpengaruh terhadap struktur modal pada perusahaan BUMN Indonesia pada tahun 2015 - 2018. Hal ini menunjukkan besar kecilnya net profit margin yang diperoleh perusahaan bukan menjadi dasar dalam menentukan tingkat utang dalam susunan struktur modal. Namun perusahaan telah menetapkan struktur modalnya berdasarkan besarnya manfaat (return) dan pengorbanan (biaya modal) yang dihasilkan dari penggunaan hutang untuk mendukung operasional perusahaan. Hal ini berdasarkan trade off theory yang menyatakan bahwa terdapat rasio hutang yang optimal dalam keuangan perusahaan. Penelitian ini sejalan dengan Widayanti et al., (2016) dan tidak sejalan Wijaya and Utama (2014), Dewi and Sudiartha (2017) dan (Hauteas and Muslichah, 2019).

Kebijakan dividen pada penelitian ini juga berpengaruh terhadap struktur modal dengan arah negatif yang ditunjukkan dengan nilai koefisien dividen payout ratio sebesar -0,384. Hal ini menunjukkan ketika perusahaan BUMN memiliki dana dan tidak dibagikan kepada pemilik saham, maka modal sendiri perusahaan BUMN akan semakin besar. Demikian juga sebaliknya ketika dana yang ada justru dibagikan sebagai dividen, maka modal sendiri perusahaan BUMN akan semakin sedikit. Hasil ini sesuai dengan teori pecking order yang menyatakan ketika manajemen perusahaan ingin memaksimumkan nilai untuk pemegang saham saat ini, maka ada kecenderungan bahwa perusahaan mempunyai prospek yang cerah, manajemen tidak akan menerbitkan saham baru tetapi menggunakan laba ditahan. Sebaliknya, apabila prospek perusahaan dinilai buruk, manajemen akan menerbitkan saham baru unuk menambah dana perusahaan. Penelitian ini sejalan dengan Eviani (2015) dan tidak sejalan dengan Ulfah (2016).

Struktur modal tidak berpengaruh terhadap nilai perusahaan. Hal ini menunjukkan bahwa kenaikan dan penurunan struktur modal dalam hal pembiayaan terhadap modal perusahaan BUMN tidak mempengaruhi nilai perusahaan yang tetap. Menurut teori trade-off, dalam kaitan penggunaan hutang optimal untuk meningkatkan nilai perusahaan dalam penelitian ini mungkin 
belum optimal. Ini menunjukan nilai modal yang lebih besar dibandingkan hutang pada sebuah perusahaan belum bisa menunjukkan kemampuan perusahaan dalam pengoptimalan penggunaan hutang untuk meningkatkan nilai perusahaan. Besar kecilnya hutang yang dimiliki perusahaan tidak terlalu diperhatikan oleh investor, karena investor lebih melihat bagaimana pihak manajemen perusahaan mengunakan dana tersebut dengan efektif dan efisien untuk mencapai nilai tambah bagi nilai perusahaan. Penelitian ini sejalan Kayobi and Anggraeni (2015) dan Thaib and Dewantoro (2017) dan tidak sejalan dengan Supit et al., (2015) dan Hauteas and Muslichah (2019).

Struktur modal tidak mampu memediasi atas pengaruh profitabilitas terhadap nilai perusahaan. Profitabilitas mempunyai pengaruh langsung yang tidak signifikan terhadap nilai perusahaan, dan ketika dimediasi oleh struktur modal tidak mempunyai pengaruh juga terhadap nilai perusahaan. Sebagaimana pecking order theory, perusahaan dengan profitabilitas yang tinggi dapat menggunakan dana internal terlebih dahulu sebelum menggunakan hutang untuk memenuhi keputusan pendanaan perusahaan untuk operasional perusahaan. Untuk perusahaan BUMN yang profitable cenderung menggunakan pendanaan eksternal. Namun tidak berdampak pada peningkatan nilai perusahaan. Hal ini dikarenakan penggunaan hutang optimal untuk peningkatan nilai perusahaan dalam penelitian ini mungkin belum optimal. Penelitian ini tidak sejalan dengan Musabbihan and Purnawati (2018) dan Hauteas and Muslichah (2019).

Hasil penelitian ini menunjukkan struktur modal tidak memediasi atas pengaruh kebijakan dividen terhadap nilai perusahaan. Apabila tingginya kebijakan dividen diikuti dengan tingginya struktur modal perusahaan hingga melebihi batas optimal maka itu akan menyebabkan penurunan nilai perusahaan. Pada saat struktur modal sudah berada di atas batas optimal, maka hal tersebut menandakan beban bunga yang ditanggung oleh perusahaan sudah di luar batas kemampuan perusahaan. Artinya manfaat yang diperoleh perusahaan lebih kecil dibandingkan dengan pengorbanan dari penggunaan utang tersebut sehingga menyebabkan penurunan pada nilai perusahaan BUMN. Penelitian ini sejalan dengan Musabbihan and Purnawati (2018) dan tidak sejalan dengan Hauteas and Muslichah (2019).

\section{PENUTUP \\ Simpulan}

a. Hasil penelitian ini membuktikan bahwa profitabilitas tidak berpengaruh terhadap nilai perusahaan. Semakin tinggi laba yang diperoleh dari penjualan tidak berdampak pada nilai perusahaan.

b. Hasil penelitian ini membuktikan bahwa kebijakan dividen berpengaruh positif terhadap nilai perusahaan. Semakin baik kebijakan dividen suatu perusahaan maka akan meningkatkan nilai perusahaan tersebut.

c. Hasil penelitian ini membuktikan bahwa profitabilitas tidak berpengaruh terhadap struktur modal. Hal ini dikarenakan perusahaan telah menetapkan struktur modalnya berdasarkan besarnya manfaat (return) dan pengorbanan (biaya modal) yang dihasilkan dari penggunaan hutang untuk mendukung operasional perusahaan.

d. Hasil penelitian ini membuktikan bahwa kebijakan dividen berpengaruh terhadap struktur modal. Semakin baik kebijakan dividen akan menurunkan struktur modal perusahaan.

e. Hasil penelitian ini membuktikan bahwa struktur modal tidak berpengaruh terhadap nilai perusahaan. Kenaikan atau penurunan struktur modal dalam hal pembiayaan 
tidak mempengaruhi nilai perusahaan yang tetap.

f. Hasil penelitian ini membuktikan bahwa struktur modal tidak mampu memediasi pengaruh profitabilitas terhadap nilai perusahaan. Penggunaan hutang optimal untuk peningkatan nilai perusahaan dalam mungkin belum optimal.

g. Hasil penelitian ini membuktikan bahwa struktur modal tidak mampu memediasi pengaruh kebijakan dividen terhadap nilai perusahaan. Semakin tinggi kebijakan dividen diikuti dengan tingginya struktur modal yang melebihi batas akan berdampak pada penurunan nilai perusahaan

$\mathrm{h}$

\section{Keterbatasan Penelitian}

Keterbatasan-keterbatasan dalam penelitian ini antara lain:

1. Penelitian ini hanya terbatas menggunakan perusahaan BUMN.

2. Data yang dikumpulkan dan dianalisis menggunakan analisis jalur dan menggunakan sobel test.

\section{Saran Penelitian}

Dengan adanya beberapa keterbatasan penelitian di atas, peneliti memberikan beberapa saran yang diharapkan dapat menjadi referensi bagi penelitian selanjutnya, yaitu:

1. Penelitian selanjutnya diharapkan menggunakan banyak sektor perusahaan agar hasil penelitian bisa digeneralisasikan.

2. Penelitian selanjutnya dapat menggunakan metode lain seperti SEM, AMOS.

\section{DAFTAR PUSTAKA}

Anjarwati, K., Chabachib, M., Demi, I.R., 2015. Pengaruh Profitabilitas, Size, Dan Likuiditas Terhadap Nilai Perusahaan Manufaktur Di Indonesia Dengan Struktur Modal Sebagai Variabel Intervening.
Diponegoro J. Financ. 6, 1-20.

Antoro, A.D., Hermuningsih, S., 2017. Kebijakan Dividen Dan Bi Rate Sebagai Pemoderasi Likuiditas, Profitabilitas, Dan Leverage Terhadap Nilai Perusahaan Perbankan Yang Terdaftar Di Bei Tahun 2011-2017. Upajiwa Dewantara 2, 58-75.

Ardimas, W., Wardoyo, 2014. Pengaruh Kinerja Keuangan Dan Corporate Social Responsibility Terhadap Nilai Perusahaan Pada Bank Go Publik Yang Terdaftar Di BEI. BENEFIT J. Manaj. dan Bisnis 18, 57-66.

Chandrarin, G., 2017. Metode Riset Akuntansi Pendekatan Kuantitatif. Salemba Empat, Jakarta.

Culata, P.R.E., Gunarsih, T., 2012. Pecking Order Theory and TradeOff Theory of Capital Structure: Evidence from Indonesian Stock Exchange. The Winners 13, 40-49.

Dewi, D.A.I.Y.M., Sudiartha, G.M., 2017. Pengaruh Profitabilitas, Ukuran Perusahaan, Dan Pertumbuhan Aset Terhadap Struktur Modal Dan Nilai Perusahaan. E-Jurnal Manaj. Univ. Udayana 6, 2222-2252.

Dhani, I.P., Utama, A.. G.S., 2017. Pengaruh Pertumbuhan Perusahaan, Struktur Modal, Dan Profitabilitas Terhadap Nilai Perusahaan. J. Ris. Akunt. Dan Bisnis Airlangga 2, 135-148.

Erawati, T., Sihaloho, D.M., 2019. Pengaruh Struktur Modal, Kinerja Keuangan, Pertumbuhan Perusahaan, dan Kebijakan Dividen Terhadap Nilai Perusahaan. J. Akunt. Pajak Dewantara 1, 113-128.

Eviani, A.D., 2015. Pengaruh Struktur Aktiva, Pertumbuhan Penjualan, Dividend Payout Ratio, Likuiditas Dan Profitabilitas Terhadap Struktur Modal. J. Akunt. dan Sist. Teknol. Inf. 11, 194-202.

Farisa, N.A., Widati, L.W., 2017. Analisa 
Profitabilitas, Likuiditas, Pertumbuhan Penjualan, Struktur Aktiva Dan Kebijakan Dividen Terhadap Struktur Modal. Pros. Semin. Nas. Multi Disiplin Ilmu Call Pap. UNISBANK Ke-3 (SENDI_U 3) 640-649.

Furqoni, M.H., Asandimitra, N., 2019. Pengaruh Faktor Fundamental Terhadap Nilai Perusahaan Pada Sektor Properti Dan Real Estate. J. Ilmu Manaj. 7, 1165-1178.

Gunawan, L., 2016. Pengaruh Net Profit Margin dan Total Asset Turnover Terhadap Nilai Perusahaan Pada Sektor Industri Barang Konsumsi Yang Terdaftar Di Bursa Eefek Indonesia. J. Ilm. Sekol. Tinggi Ilmu Ekon. Widya Dharma Pontianak 07, 22-31.

Harjito, D.A., 2011. Teori Pecking Order dan Trade-Off dalam Analisis Struktur Modal di Bursa Efek Indonesia. J. Siasat Bisnis 15, 187196.

Hauteas, O.S., Muslichah, 2019. Analisis Pengaruh Profitabilitas dan Kebijakan Dividen terhadap Nilai Perusahaan dengan Struktur Modal sebagai Variabel Mediasi. J. Manaj. dan Keuang. 8, 177.

Husnan, S., Pudjiastuti, E., 2012. Dasardasar Manajemen Keuangan, Keenam. ed. UPP STIM YKPN, Yogyakarta.

Indasari, A.P., Yadnyana, I.K., 2018. Pengaruh Profitabilitas, Growth Opportunity, Likuiditas, dan Struktur Modal Pada Nilai Perusahaan. E-Jurnal Akunt. 22, 714.

Kayobi, I.G.M.A., Anggraeni, D., 2015. PENGARUH DEBT TO EQUITY RATIO (DER), DEBT TO TOTAL ASSET (DTA), Dividen Tunai, dan Ukuran Perusahaan Terhadap Nilai Perusahaan. J. Akunt. dan Keuang. 4, 100-120.

Khoirianto, R., 2016. Pengaruh
Profitabilitas dan Kebijakan Dividen Terhadap Nilai Perusahaan dengan Struktu Modal Sebagai Variabel Intervening. Akuntabilitas 9.

Kusumastuti, W.F., Setiawati, E., Bawono, A.D.B., 2017. Pengaruh Profitabilitas Dan Struktur Modal Sebagai Variabel Moderasi (Studi Pada Perusahaan Property Dan Real Estate Yang Terdaftar Di Bursa Efek Indonesia Tahun 2015- 2017). Semin. Nas. dan 6th Call Syariah Pap. Univ. Muhammadiyah Surakarta 275-295.

Lestari, S., 2015. Determinan Struktur Modal Dalam Perspektif Pecking Order Theory dan Agency Theory ( Studi Empiris Pada Perusahaan Manufaktur yang Listing di BEI. J. WRA 3, 571-590.

Mispiyanti, 2020. Pengaruh Struktur Modal , Capital Expenditure , Profitabilitas Dan Kebijakan Dividen Terhadap Nilai Perusahaan Pada Perusahaan BUMN Indonesia. J. Akunt. Pajak 20, 133-144.

Musabbihan, N.A., Purnawati, N.K., 2018. Pengaruh Profitabilitas Dan Kebijakan Dividen Terhadap Nilai Perusahaan Dengan Struktur Modal Sebagai Pemediasi. E-Jurnal Manaj. Univ. Udayana 7, 1979.

Purnomo, E., Erawati, T., 2019. Pengaruh Profitabilitas Terhadap Nilai Perusahaan Dengan Struktur Modal Sebagai Variabel Intervening (Studi Kasus pada Perusahaan Manufaktur yang Terdaftar di Bursa Efek Indonesia Tahun 2012- 2016). J. Akunt. dan Keuang. 1, 37-57.

Rasyid, F.A., Yuliandhari, W.S., 2018. Pengaruh Biaya Corporate Social Responsibility dan Kebijakan Dividen Terhadap Nilai Perusahaan (Studi Pada Perusahaan BUMN yang terdaftar di Bursa Efek Indonesia 2012 - 2016). J. Akunt. Bisnis Ekon. IV.

Rohmah, I.L., Wahyudin, A., 2015. 
Pengaruh Environmental Performance Terhadap Economic Performance Dengan Environmental Disclosure Sebagai Variabel Intervening. Account. Anal. Journa $4,1-13$.

Rosada, F.L.A., Idayati, F., 2017. Pengaruh Profitabilitas Terhadap Nilai Perusahaan Otomotif Di Bursa Efek Indonesia. J. Ilmu dan Ris. Akunt. 6, 258-274.

Senata, M., 2016. Pengaruh Kebijakan Dividen Terhadap Nilai Perusahaan Yang Tercatat Pada Indeks LQ-45 Bursa Efek Indonesia. J. Wira Ekon. Mikroskil 6, 73-84.

Supit, H.V., Herman, K., Jenny, M., 2015. Pengaruh Struktur Modal, Biaya Ekuitas, dan Kebijakan Dividen Terhadap Nilai Perusahaan Pada Badan Usaha Milik Negara (BUMN) Yang Terdaftar Di Bursa Efek Indonesia. J. Ris. Akunt. dan Audit. "GOODWILL" 1, 1-18.

Thaib, I., Dewantoro, A., 2017. Pengaruh Profitabilitas dan likuiditas terhadap nilai perusahaan dengan struktur modal sebagai variabel intervening. J. Ris. Perbank. Manaj. Dan Akunt. $1,25-44$.

Ulfah, A., 2016. Faktor-faktor yang Mempengaruhi Kebijakan Dividen dan Dampak Kebijakan Dividen Terhadap Struktur Modal Bank BUMN Periode 2005 - 2014. Perbanas Rev. 2, 1-16.

Widayanti, L., Triaryati, N., Abundanti, N., 2016. Pengaruh Profitabilitas, Tingkat Pertumbuhan Perusahaan, Likuiditas, Dan Pajak Terhadap Struktur Modal Pada Sektor Pariwisata. E-Jurnal Manaj. Unud 5,
3761-3793

Widyanti, R.A.Y.U., 2014. Pengaruh Profitabilitas, Dividend Payout Ratio, dan Corporate Social Responsibility Terhadap Nilai Perusahaan Sektor Manufaktur. J. Ilmu Manaj. 2, 1048-1057.

Wijaya, I., Utama, I., 2014. Pengaruh Profitabilitas, Struktur Aset, Dan Pertumbuhan Penjualan Terhadap Struktur Modal Serta Harga Saham. E-Jurnal Akunt. 6, 514-530.

Zurohtun, Yulianti, R., 2013. Kebijakan Dividen Pada Perusahaan Konservatif Dan Non Konservatif Serta BUMN Dan Non BUMN. J. Ilm. Akunt. dan Bisnis 8, 1-8. 